\title{
4
}

\section{Conceptualizing Change in the Cuban Revolution}

\author{
Marina Gold
}

"Change is the very condition of human existence," states Kapferer (2006, 125) in his analysis of Max Gluckman's An Analysis of a Social Situation in Modern Zululand (1940). In his essay, Gluckman points to the importance of analyzing change, as forms of social and political life are in continual flux. There is no essential initial condition from which to appreciate change, and any glimpse of social moments yields a snapshot

\footnotetext{
${ }^{1}$ Founded in 1947 by Max Gluckman, the Department of Anthropology at the University of Manchester became known as "the Manchester school" for developing innovative methodological and theoretical tendencies in the discipline. A focus on case studies, a concern with conflict and social organization characterized its foundational years.
}

I would like to thank the Institute for Social Anthropology and Empirical Cultural Studies at the University of Zurich for supporting me during the writing of this paper with an Associated Researcher position and a collegial working environment. This research was carried out with the financial and institutional support of a research fellowship at the University of Bergen under the European Research Council Advanced Grant awarded to Prof. Bruce Kapferer for the project 'Egalitarianism: Forms, Processes, Comparisons'.

\section{Gold ( $\square)$}

University of Zurich, Zurich, Switzerland

Y. Berriane et al. (eds.), Methodological Approaches to Societies in Transformation, Anthropology, Change, and Development, https://doi.org/10.1007/978-3-030-65067-4_4 
within an open process. One of the concerns of the Manchester school ${ }^{1}$ has been to understand social processes in constant flux, a reaction at the time to functionalist thought in anthropology, which tended to produce a more stagnant view of an integrated cultural/social whole. Therefore, the Manchester school aimed to contribute detailed and grounded ethnography that could be periodically reviewed and reconsidered from various theoretical perspectives (Gluckman 1940). Gluckman (1979) also notes the importance of time, both past and future, in considering the fluid nature of processes and the interconnectedness of events. This involves contemplating the study of change at three levels: change in the structures of lived experience (the unit of analysis), change that is observable in particular events, which become moments of condensation of the processes of social situations (empirical data), and change in the theories of knowledge through which these events are interpreted (metanarratives of change) (see also Introduction).

The question raised by the editors of this collection-how anthropologists and other social scientist study change-is particularly relevant in the case of Cuba, as change not only represents a methodological challenge, given the paradox of studying an ongoing revolutionary process, but is also charged with ideological connotations. The metanarratives of change and continuity in the academic literature on Cuba inform political positioning in relation to the revolution. These, however, must be subsumed to Cubans' daily experiences, better grasped through longterm ethnographic research, which reveals the partialities and contradictions of people's conceptualization of revolution. Ethnography, however, is hardly repetitive and, critically, event-filled, where the "event" is understood as "a singularity in which critical dimensions can be conceived as opening to new potentialities in the formation of social realities" (Kapferer 2010,1). In this respect, the practical obstacles that prevent social scientists engaging in long-term fieldwork today can (arguably) be overcome to a certain degree by considering the importance of the event for the study of any social process, especially in cases of long-term engagement with a place with whose historic processes, general debates, and local nuances the researcher is familiar.

This chapter explores one way of studying change ethnographically (and theorizing it anthropologically) in a context where change is 
heralded by some as progress while others disregard the trope as an ideological mechanism of anti-revolutionary views. That is, in the context of a political system that characterizes itself as a permanent revolution (see Gold 2015), change is a constant reference in terms of both political discourse and the materialities of people's lived experiences. Underlying these tensions about the nature and meaning of change are conflicting and shifting dynamics of relations, making the idea of "change" an ongoing and contested condition. Therefore, when change is the constant condition, what one perceives is the process or dynamics by which it occurs, which are of course neither constant nor linear. A possible snapshot of these processes is given by events, including both large-scale, transcendental events - such as the death of Fidel Castroand more inconspicuous, small-scale shifts (a new law, a marriage, a migration) in people's lived experiences. In this way events can manifest tensions and contradictions as well as structures and orders, and are not just reflections of the past but crucibles of unrealized potential (Kapferer $2010,15)$. In an attempt to explain how change is understood and studied in relation to the Cuban Revolution, I consider how the social and political processes that shape people's lives as part of a perpetual revolution (explained below) can be gauged through events- public and private, grand and small-that provide a snapshot of the complex and contradictory dynamics of sociopolitical life in Cuba. Therefore, the units of analysis for this purpose are twofold: the large-scale national project of revolution, and people's everyday experiences of it. The empirical data I engage with was collected during consecutive fieldwork trips between 2008 and 2016, and ongoing long-distance email and WhatsApp communications with informants, official media, informal digital media, and scholarly material. I pick two radically different events, precisely for their very different scales: the death of Fidel Castro as it was perceived by my informants, in the public media, and in published accounts; and a series of small-scale events in the life of one woman who is not extraordinary in any way but whose aggregated stories reflect many of the changes regularly taking place in Cuba. Thirdly, the metadata analysis provides the framework for the political and ideological context to the study of change in Cuba, to understand why both events are important in considering the implications of studying change. 
Life in Cuba is framed by the concept of revolution, and the meaning of revolution is not self-evident. After a brief clarification of the implications of the revolution in Cuba and the political debate behind the notion of change (the metanarratives), I consider how different events unpack the processes and dynamics underpinning social interactions in Cubans' daily lives. The death of Fidel Castro, I argue, is a transcendental event in the history of the revolution, and acts as a moment of intensification; but this alone is not enough to understand how change is effected in people's daily lives. While transcendental events can serve to materialize and problematize underlying tensions and processes of change, imperceptible events and random occurrences can often crystallize the complexities and ambiguities of sociopolitical processes more clearly (see Moore 2006). Both types of events provide a view of life within the revolution.

\section{Revolution: Change and Continuity}

Elsewhere (Gold 2015) I have explored the multiple implications of the concept of revolution in Cuba in detail (see also Holbraad 2014), informed by the notion of perpetual sacrifice and struggle. As such, revolution in Cuba is not a rigid state ideology but rather a negotiated, lived practice (see also Gordy 2015). In people's daily lives the complexities of living in a perpetual state of revolution are evident (see for example Gold 2011, 2016). People must negotiate shifting nuances in state ideology regarding the limits of revolutionary practice while simultaneously shaping the potentialities of revolution through their own actions. For example, émigré Cubans were once repudiated as traitors and political defectors but since the 1990s, with the collapse of the Soviet Union and the hardships of the Special Period, émigré Cubans who sent remittances to the island were recognized as an extension of revolutionary participation from abroad (see Gold 2015; Eckstein and Barbeira 2002). This shift in the state's attitude toward the diaspora was not effected only from above; it was initiated from below through people's reconnection with family members overseas, and then captured by state mechanisms through the taxation of remittances, the opening up of dollar-stores that 
allowed the state to collect hard currency, and the provision of money transfer services such as Western Union.

Revolution, as ideology and practice, is embedded within the social milieu of Cuban life. It is partly a state ideology, partly a discourse of nationalism, and partly a set of practices and habits. What constitutes a "good revolutionary" has changed throughout the 60 years of the process. The construction of the Cuban nation is based on the notion of revolution. Therefore, ideology is only one level of revolutionary understanding. In Cuba, revolution as ideology acts as a system of classification, a normative system, but it is also embedded in daily practices, since it acts as a system of structures that guide people's actions. As such, revolution implies tacit understanding of what is good and what is inappropriate. These "implicit meanings" (Douglas 2001) of revolution have changed throughout history, altering how people position themselves in relation to the state, the nation, and the concept of revolution.

In the 1960s the subject and actor of the revolution was a communal one-el pueblo (the people) —and any action that foregrounded the individual's interest was considered anti-social and counterrevolutionary. Through this discourse many were excluded and marginalized from the political project: homosexuals, the bourgeoisie, people who refused to participate in mass campaigns such as the literacy campaign. Since the 1990 s, and more poignantly in the last ten years, the revolutionary subject has become atomized, reduced from "the people" to the neighborhood, the family, and more recently to a much more individualized understanding of revolutionary commitment. Therefore, just as practices of revolution have never been stable, so the conceptualization of revolutionary ideology is also in constant flux.

\section{Metanarratives of Change: Reform or Revolution?}

In the context of studying a process of revolution, conceptualizing change takes on additional challenges. Revolutionary processes are premised upon a partition between "before" and "after" which is always politically and situationally defined. This then demands exploration of 
the process of change/alteration, and the before/after of that which is being revolutionized. The processes of change are contested by structures that subsist, often undermining the revolutionary struggle, such as different forms of inequality (gender, class, power). Simultaneously, for the Cuban Revolution in particular, it has been fundamental to establish a long durée connection between the current political project and the anti-colonial struggles of the nineteenth century. The meaning of revolution in Cuba is not a foregone conclusion. Since the 1990s, when the Soviet Union collapsed, a surge of scholarship aimed to understand the nature of the Cuban Revolution in the context of a radically transformed sociopolitical scenario. Many argued that revolution in Cuba is nothing more than the stagnant state ideology of an authoritarian regime (Kaufman Purcell 1991; Sweig and Bustamante 2013). And yet, in spite of the indescribable hardships of the Special Period (the decade of the 1990s), the Cuban Revolution subsists.

The meaning of revolution became crucial because the collapse of the Soviet Union raised the following question: how is it possible that the Cuban Revolution subsisted amidst the radical global changes of the 1990s? Subsist it did, but not unchanged, and such change has been the focus of countless scholarly studies (Bray and Woodford Bray 2002; Brotherton 2005; Brundenius 2002; Bye 2013; Pickel 2008) taking various political positions on Cuba. For anti-Castro voices conceptualizing Cuba as a "society in transition," change is an imminent possibility that will transform Cuba from a communist prison to a democratic (and by extension capitalist) paradise (Romeu 2005; Russo 2013). Change has been used as an indicator on the democracy/authoritarianism scale, and has been measured through studies of civil society (Armony 2003; Abreu 2008), religion (Berry 2010), artistic representation (Fernandes 2006), and corruption (Bain 2008). For observers more sympathetic to the revolutionary project, change implies an ongoing process: change from the colonial republic of Batista to the revolutionary government of "los barbudos" ; change first toward and then away from Soviet models in the 1960s and 1970s; change from Fidel to Raul in the first decade of the

\footnotetext{
${ }^{2}$ The bearded ones, referring to Fidel Castro, Camilo Cienfuegos, Che Guevara, and other guerrilla fighters.
} 
twenty-first century; and a possible change away from the parameters of the revolutionary project (Kapcia 2009). Studies of change in the Cuban Revolution have often overlooked the importance and multivalence of this enduring trope.

The death of Fidel Castro was the spark that set off the latest in the long history of clairvoyant scholarship about the fate of Cuba. Historical moments of crisis intensification have attracted the attention of scholars and raised the question "what next?" This question always implies two political views: will Cuba finally change and embrace capitalism and democracy, or will it remain the same, stagnant, failed state? ${ }^{3}$ Conversely, the other view asks whether Cuba will finally succumb to the pressures of the market and relinquish its social achievements, or will be able to change within the parameters of the revolutionary project. ${ }^{4}$ In both positions, change refers to the nature of the state, and the concern is with the structures that presumably embody the revolution.

This concern is not uniquely directed at Cuba: change has also been a trope for understanding political transformation elsewhere. In the 1980s and 1990s most of Latin America underwent structural adjustment programs, which had at their core a particular state model and the entrenchment of the US as the neocolonial power in the region. The broader historic context of this intervention is of course the long and farreaching influence of the US in most military governments that assailed Latin America in the 1960s and 1970s. In this context, argues Cuban academic Rafael Hernández (2010), reform and revolution are seen as dichotomous: the former is espoused by North American scholars and politicians in order to counteract the supposed stagnation of the latter. Embedded within studies of change as reform are deeply rooted notions of progress and development (Escobar 2001), applied not only to Cuba and Latin America but also to the Global South more generally (Escobar 2004; Willis 2005; McMichael 2012). These concerns, coupled with

\footnotetext{
${ }^{3}$ Some of the representatives of this view include: Otero and O'Bryan (2002), Pumar (2009), Corrales (2001), and Pickel (2008).

${ }^{4}$ This view is largely espoused by Cuban academics and Latin American observers of the revolution (Guanche 2008; Hernández 2010; Acanda 2000, 2002; Carranza Valdés 1991; González Cruz 2010). It is also the view of Cubans commenting on their blogs (see for example Fernández Estrada 2017; Rodríguez Rivera 2016).
} 
political expectations shaped by the Cold War, have underscored studies of change in Cuba. Against this backdrop, how is change lived within the Cuban revolution?

The death of Fidel Castro represents what Badiou (2007) would call "an epochal event": an event that will come to define a particular shared experience. Through this event yet again the trope of change has come to the fore in Cuban politics and scholarship. The much-awaited (by some) and dreaded (by others) event of Fidel Castro's death did not see the fall of the revolutionary project. In concrete terms, Cubans' lives have been in constant flux, even while occasionally marked by radical events such as the collapse of the Soviet Union or, more recently, the wane of the Pink Tide. In contrast, many of my informants have a typical answer to the question "How are things?": "Ya tu sabes. Acá estamos, resolviendo. Nada ha cambiado" (You know. Here we are, resolving. ${ }^{5}$ Nothing's changed). However, when I observe their lives, or at least their material welfare, I can see that much has changed since I first met them: many have managed to improve their homes, some have purchased a new house, others or their children have migrated, and a few have moved into the private employment sector. All of these changes have significant political implications in Cuba and respond to larger structural transformations. I focus now on how change can be understood by looking both at transcendental events (the death of Fidel Castro) and inconsequential events (a woman's quest to improve her house), arguing that both sociopolitical analysis and the details of people's lived experiences provide crucial insights into the study of change.

\section{The Death of Fidel Castro}

During my long-term research in Havana between 2008 and 2012 I had a fantasy of living through what I prematurely considered would be the end of the revolution: the death of Fidel. When I settled in Havana for fieldwork in 2009 Fidel had already stepped down from his role in

\footnotetext{
5In Cuba "resolving" something implies sorting out the daily needs—getting food, medication, construction materials, a trip overseas — by both formal and informal economic means.
} 
government and Raúl Castro had officially been voted President of the island. I considered, not without trepidation, the moment of waking up one morning to read in the papers that Fidel was dead. It would be, I imagined, like seeing the Berlin Wall being torn down. As it happened, Fidel outlived my fieldwork period by a good four years. But another anthropologist got to experience the surreal and exceptional moment. Martin Holbraad was in Cuba at the time of Fidel's death and wrote an account of his experience (Holbraad 2017). I borrow from this account and complement it with my informants' reactions and media reports in my analysis of how the event of Fidel Castro's death contributes to understanding change.

On the 25 of November 2016 I opened the newspaper and saw the news: "Fidel Castro is dead." It was not an unexpected occurrence, since the revolutionary leader had turned 90 in August that year and had been forced to retire from office in 2006 due to health problems, ceding power to his brother. While his death sparked demonstrations of joy in Miami and sorrow in Cuba, the Cuban revolution did not collapse and the US military did not invade Havana (even though Trump could not refrain from sending a provocative Tweet about "the dictator's death").

While anti-Castristas celebrated on the streets of Miami with chants of "se murió la momia," "the mood in Cuba remained introspectively calm. On that chilly November day there was "something forlorn on the faces of the people" (Holbraad 2017). Holbraad's landlady, "an exemplary case of what the revolution has done for ordinary people in Cuba,"7 had been crying and was profoundly upset by Fidel's death. She was a declared Fidelista, though she would not call herself a revolutionary. ${ }^{8}$ This is a crucial distinction in terms of appreciating change in revolutionary discourse, as well as in people's expression of support for the sociopolitical project. Other people that Holbraad encountered declared that they

\footnotetext{
6"The mummy is dead."

${ }^{7} \mathrm{He}$ refers to education opportunities for Afro-Cubans, the option of living in the city and getting a house, and the creation of mass organizations such as the Federation of Cuban Women, which served to empower a much-repressed section of the population.

${ }^{8}$ Many people of her generation, who were in school in the 1960 s and were shaped by a revolutionary education-declare themselves Fidelistas but not revolutionaries, as in the case of Aleyda, below.
} 
had lost a father; this was a common way of conceiving Fidel, and is not a simplistic case of political paternalism but rather more complexly involves affective power and the importance of kinship in Cuba (see Routon 2010; Härkönen 2016). My informants were also affected by the news, even those who were living overseas in Spain or France. But none worried about what would happen next. Quite the opposite: they understood that the event would not bring about immediate change, as two of Holbraad's acquaintances revealed. The first was a young friend he ran into on the street who said about Fidel: "He lived his life, and now he's dead. We are the ones who have to carry on living in this," conveying an understanding of the continuation of the situation beyond his death. A woman working as a cleaner in a guest house told Holbraad of the increased control and surveillance of foreigners and Cubans alike in order to "keep things under control" at a complicated time; her mother added that "they [the government] know what they are doing."

Events in the ensuing days followed a familiar pattern: a state of national alert at the important government service departments (logistics, secret services, army, immigration), control of the news and the Internet, double checks on foreigners on the island, the mobilization of buses to take people to the funeral procession, and a large military and police presence to guarantee order. Old documentaries and speeches by Fidel were republished in the official media, interrupting the daily Brazilian soap opera; important sports, and arts personalities and academics made statements in public blogs or news spaces. Demonstrations by the Damas de Blanco ${ }^{10}$ would not have been covered by media. The government was well prepared for the event, and, in many ways, so were the people.

It was not an event that shook the foundations of the revolutionary project, because people have long come to embody the struggle that revolution demands in myriads of ways beyond the political structures of the state (Pertierra 2006; Holbraad 2014; Premat 2003; Gold 2015). What,

\footnotetext{
${ }^{9}$ As Holbraad explains, 'this' (esto), refers to an aggregate of ideas connected to the ambiguity of the concept of revolution (society/country/socialism/revolution/present moment).

${ }^{10}$ Ladies in White is a group of women whose husbands, brothers, or fathers were arrested for political dissidence. They wear white to Mass on Sundays and regularly protest about different issues (relations with the US; church-state relations; emigration matters, etc.). On Fidel Castro's death they decided not to demonstrate as a show of respect for the national state of mourning.
} 
then, does this event reveal about change in Cuba? In many ways it condensed changes that had already been in place: the end of a discursive era of endless political speeches and ideological battles; increasing conflict between the generation that had lived through the revolution and that born after the Special Period, who never saw its benefits; redefinition of the meaning of revolution and people's commitment to it. Fidel had already passed into the pantheon of revolutionaries occupied by Martí, Mella, and Guevara. The seemingly monumental event of the disappearance of the "historic leader" ${ }^{11}$ of the revolution, while it most certainly signified the end of an epoch, did not induce immediate change.

The death of Fidel did not trigger the onset of the most radical changes that have been transforming Cuban social, political, and economic life. Some of these changes are particular to any life course, such as the generational transition of ideas and expectations affecting Cuba, now that those born in the late 1980s and 1990s are coming of age. This generation, ${ }^{12}$ with less affective ties to the legacy of their grandparents and great-grandparents and more exposure to the allures of capitalism through the Internet, have a different outlook on the future. However, a more concrete event that has been creating radical transformation in economic and political ideas has been the legalization of real estate in 2014. This, and Obama's denouncement of the economic blockade as a failed policy, produced more immediate and radical transformations. To explore how these changes impacted on Cuban daily lives, I now shift the focus from transcendental events and look at people's daily lives to appreciate how the small-scale events that define their routine reveal the larger transformational dynamics of their sociopolitical context.

\footnotetext{
${ }^{11}$ This is how Cuban politicians and the Communist Party started to refer to Fidel after he retired from office. It represented a slow but purposeful process of repositioning revolutionary political discourse.

12The concept of generations is an important one in Cuban sociology, gaining traction in the 1980 s at a crucial time for revolutionary leadership when the decadence of the Socialist bloc was palpable. The generational theme was based on Marx's ([1932] 1998) thoughts in The German Ideology to explain how power ought to be transferred in order to perpetuate the revolution, while contemplating the possibility that the revolution could transform itself under different generational circumstances (for an analysis of the different Cuban generations see Domínguez 1998).
} 
The story of one particular informant, Aleyda, serves as unit of analysis to consider the impact of these less transcendental events on shaping life within the revolution. This woman's story epitomizes many larger themes of change in Cuba: migration, the emergence of private property, the precarization of labor, intergenerational conflict, and political apathy. Her extended case reveals the contradictions between large-scale changes and people's lived experience.

\section{Aleyda: From the Solar to the Casa Particular ${ }^{13}$}

In 2009, when I was doing my Ph.D. fieldwork, Raúl Castro had been officially elected and there was a degree of expectation that things could change. Raúl Castro's concern was to streamline the economy, and he initiated a process of internal debate that was announced in 2010 as the Proyecto de Lineamientos de la Political Económica y Social. ${ }^{14}$ In 2016 the Lineamientos document was still being circulated in the second round of consultations. However, even while things seemed to stay the same from the people's viewpoint, there were important changes that had radical impacts on their lives, such as the legalization of private property in 2014. Aleyda's story crystallizes some of the ways in which this event transformed people's lives. In order to understand the impact of such an event, I must first briefly present Aleyda's situation.

Aleyda worked as a cleaner for my first landlady in 2009. She was in her late sixties and had indigenous and African heritage. She had a 17-year-old daughter, who at the time was starting medical school but later changed her major to information technology, because being a doctor would make it harder for her to leave Cuba. ${ }^{15}$ Aleyda's elder son was 27 and was a mechanical engineer. Aleyda had been forced to

\footnotetext{
${ }^{13} \mathrm{~A}$ solar is a type of communal housing where families live in small one-room apartments and share a common patio. Sometimes they share other facilities such as a kitchen or washing area. This particular solar was in Playa. a casa particular (private house) means a house that has been refurbished for rental, preferably to foreigners.

${ }^{14}$ Draft 'Guidelines for the economic and social policy of the Communist Party of Cuba.'

${ }^{15}$ In 2009 travel restrictions in Cuba were strict and doctors, highly valued social capital for the revolution, were prevented from travelling overseas to prevent their defection.
} 
stop working by her last husband, but after the divorce and once her daughter had started university she obtained a state job working for the Banco Financiero (Financial Bank) collecting payment for state credits. ${ }^{16}$ She had to go back to work because she still had to comply with her life-quota of work hours. ${ }^{17}$

With the transformation of work from purely state-controlled, to the appearance of foreign investments and the more recent proliferation of self-employment, Aleyda's (and her children's) stories reveal the changing perceptions of the value of work. Aleyda's son worked with a Canadian company installing the infrastructure for electric generators. Mixed enterprises appeared in the late 1990s as the state implemented regulations to allow foreign investment on the island. Canada, Spain, and China were some of the countries that first began investing in Cuba in spite of the tightened US embargo. Aleyda's son complained that people no longer had the will to work hard for moral incentives and the good of the country. He represents the last generation to have experienced moral incentives around work. His younger sister would not conceive of engaging in voluntary nor morally rewarded employment. In contrast, Aleyda recalled how in her youth people had worked hard because work itself had value. She had finished high school and a tertiary engineering course and started work at the Ministry of Fisheries in the packaging and distribution of catches. She had to deal with elderly fishermen who were upset at having to incorporate the changes enacted by the revolution (including having a part-indigenous woman as their boss). ${ }^{18}$ The 1960s and 1970s saw a surge of development policies, central planning, and Soviet-influenced ideology in Cuba, with progress and mechanization the central tenets of development. These would have been the ideas that Aleyda brought to the elderly fishermen. It was the first generational conflict of the revolution, with the young and vigorous governing

\footnotetext{
${ }^{16}$ These were state loans given for people to upgrade their fridges and air-conditioning systems to more energy-efficient ones in the early 2000s.

17There is a minimum number of work people must do before they can retire and earn their pensions.

${ }^{18}$ Aleyda would say she was not Afro-Cuban. This is indicative of the still-latent racial stereotyping on the island, which countless anti-racial revolutionary policies have been unable to eliminate (de la Fuente 1998; Pedraza 2004; Eckstein 2009).
} 
class aiming to modernize the country. Aleyda and her children embody shifts in the value of labor: national policies around work and retribution, equity laws, the penetration of foreign capital into the island's economy, and finally, as will be developed below, the emergence of private property and self-employment.

In terms of her personal life, Aleyda also reflects the changes put in place by the revolution: such as the reduction of class inequalities, the increased opportunity for women in the workplace, and the reduction of the influence of the role of religion. Aleyda's second husband was white and from an upper-class family. His parents owned a beautiful house in Playa. His father had been a banker before the revolution and owned his house, which he had been allowed to keep. His brother left for the US in the 1980s and was now well off. He sent US\$200 a month to his parents, and every time he came to visit, he invested in refurbishing their house. In the yard of that house there was a small two-story apartment that Aleyda and her ex-husband had built when they married. Only after the revolution would it have been possible for her, a poor indigenous woman from the country, to marry the son of a high-class family of bankers; and only after the revolution could a woman divorce multiple times without suffering social stigma. She was proud of these facts.

In 2009 the little apartment in the yard was rented out to an Italian and his wife for three years, although technically only one room was left. This was common, as it allowed landlords to pay the tax on the rental of a single room, which in 2009 cost between CUC 25 and 45 a day (which would cost between CUC 750 and CUC 1350 a month for a room), while actually renting the whole house for anything between CUC 3000 and 6000 a month, enabling them to make a large margin of profit. This phenomenon emerged in the 1990s with the proliferation of tourism and the slow and cumbersome bureaucracy that aimed to continue centralizing self-employed activities (see Armengol 2013 and Gold 2016 for an analysis of the rental property market).

After her second divorce, Aleyda moved to a one-bedroom unit with her daughter, who was still underage. Aleyda was perpetually obsessed with improving her unit. In 2016, when I last visited, she had managed to build two further stories upward, which still had no doors or windows. However, soon she would have an extra room and a bathroom, a terrace 
and a water tank, important in Havana as piped water only flows for a few hours a day. Despite these improvements, Aleyda complained about the high cost and lack of availability of construction materials and tradesmen's lack of reliability. This was a common complaint of many of my informants from 2009 to 2016, because tradesmen work in cooperatives or government firms and have to do their private work por la izquierda (on the side). They also have to obtain materials for their privately organized work illegally, since the state firm that sells construction material monopolizes the market, making materials extremely expensive and scarce.

In spite of her complaints about her stagnant situation, many things had changed in 2016 when I last saw Aleyda. Her daughter had illegally left for the US via the Mexican border and had married a Cuban American, purely in order to get a green card. Now she is divorced and has a boyfriend, also a Cuban American.

The most radical change in Aleyda's life in 2016 was that she had become a property owner, and the manager of a rental property (casa particular), and all thanks to her Spanish friend Carlos Alfredo. Carlos Alfredo, a Spanish man in his 80 s, had been visiting Havana since the opening up of the tourist market in the 1990s. He was one of the many European men who flock to Cuba in the European winter as sex tourists (Wonders and Michalowski 2001; Berg Rundle 2001). They met when Aleyda was working as a cleaner in the casa particular where he always stayed. Renting out a room to tourists had become first an informal practice and then an official and regulated policy in the 1990s as a way of accessing hard currency and catering for the increasing tourism before the state was able to catch up on the necessary infrastructure in the early 2000s. It is now a common self-employed activity.

Aleyda and Carlos Alfredo got married in 2015, when he wanted to buy a house. In one of the most important policy changes in recent years, in 2014 Raúl Castro legalized the sale of houses, which until then could only be exchanged (permuta). In spite of regulations limiting the number of properties that a person can own and excluding foreigners without a permanent residence from the property market, many unofficial mechanisms have led to foreigners and Cuban-Americans flooding the market. 
One strategy is for foreigners to marry a Cuban, obtain a permanent residence visa and buy a house. Carlos Alfredo bought a house in Playa in Aleyda's name for CUC 40,000 (the equivalent in US\$). The exchange began as an informal deal with the owners, in which he would officially rent it from them for 15 years and then return it. He started fixing up the house and eventually decided to buy it, but the owners did not want to sell, especially because he was going to put it in Aleyda's name. This meant that they would not get their property back. They negotiated an increase of CUC 20,000, and although Carlos Alfredo had already paid CUC 40,000 he agreed, considering a house for 60,000 CUC cheap by European standards. In 2009 an apartment in Centro Habana could be sold unofficially for US\$ 10,000; in 2016 there were apartments in Vedado selling for US\$ 1 million.

As soon as Carlos Alfredo bought the house he held a meeting with the neighbors and explained that while theirs was a marriage of convenience they should all support Aleyda through the process of his getting residency. Having spent many summers in Cuba, Carlos Alfredo understood that while private property was becoming more common on the island, he would still have to contend with the web of social networks that both support and undermine private activities (see Gold 2016). This has also given Aleyda Spanish citizenship (for being married to a Spaniard), in common with many Latin Americans with Spanish ancestry who claim citizenship to obtain an EU passport.

Thus Aleyda, a woman made by the revolution in her political identity, her experience of moral incentives, the opportunities to get a job as an indigenous woman, also reveals the trajectories (desired and undesired) traversed by the revolution: the proliferation of the informal economy, the generational shifts with those born in the 1990s (many of whom emigrate), and the increasing preoccupation with material concerns. Aleyda often described herself as a fervent fidelista, not a communist, stating that after he died she would no longer be a communist because to her revolution means constant change, and there has been anything but change in Cuba in the last 50 years. It was common for people to express their position on the revolution, Fidel Castro and the future, and these views were never constant and shifted subtly. The contrast between this and her comments about the importance of the revolution 
in transforming work ethics, gender, and race relations reveals the contradictory positions that people take in relation to revolution as an ongoing struggle, with the positive and negative connotations this entails, and to change more generally.

\section{Conclusion: When Change Is the Norm}

In the five years that I knew her, Aleyda went from living in a onebedroom apartment to owning two properties, with a foreign husband and an émigré daughter in the US. She also now has a phone and access to the Internet. In concrete material terms, her life has improved and embodies the political changes of the revolution and the larger global migratory currents. It also reveals how people position themselves ambiguously towards change. Aleyda's story raises important questions about the value of change: even though her life had improved materially, she was not satisfied with the political and social situation.

It is perhaps in this respect that the death of Fidel will retrospectively become relevant. At the time it did not radically transform people's existence. He had been away from public life for ten years and the people had grown accustomed, if not fond of, his brother. But the absence of Fidel will have an effect, perhaps in the intergenerational transformation that Mannheim (1954) and Marx (1998) see as key elements of social transformation. Given many Cubans' view of Fidel as a father figure, the disappearance of the disapproving father may liberate the children to abandon the dictates of a time gone by. In this way, both transcendental events and detailed lived experiences are revealing for any study of change that aims to represent the experience from both a larger theoretical and macro-structural perspective and a more phenomenologically informed view of the practices and views of those who are going through it. Change is present at both levels, but is represented in different ways. While from the official perspective, revolution changes its circumstances but always involves the struggle for and commitment to a larger sociopolitical project (variably defined), in people's lived experience revolution can be variably defined as a social network, a set of values, a cause for 
shortages, a historical moment of family histories and a shared imagined future.

Following Gluckman, when change is the norm, that which remains stable must be carefully considered. In the case of the Cuban Revolution, a process that bases its legitimacy on the very conditions of struggle and persistence, change and continuity are key tropes in the political and social analysis of Cuban life. The event of the death of the historic leader of the revolution served as a moment of crystallization of particular enduring tensions within the revolution: state control, citizens' frustrations, diasporic resistance, forms of political participation, selfreflection on revolutionary personhood, the use of political symbols, and the making of political myths in Cuba. However, it falls short of revealing the more profound changes affecting people's lives that have been taking place in the past twenty years and are, imperceptibly but enduringly, transforming key structures in Cuba: labor relations, property rights, local-global relations, and intergenerational conflict. The story of Aleyda reveals the impact of larger regional and international processes such as migration, the emergence of private property, the precarization of labor, intergenerational conflict, and political apathy through a person's lived experience. What makes this analysis particularly "Cuban" is that these processes occur within a political and ideological framework where change and continuity - in the discourse of revolution and resistanceare continuously revisited, elaborated, and transformed, not only from the top-down (as ideology), but also from the bottom-up (as practice).

\section{Bibliography}

Abreu, Reynier. 2008. “Cuba, sociedad civil e identidad: los años 90.” Revista Cubana de Filosofía 12 (Mayo-Septiembre): 16.

Acanda, Jorge Luis. 2000. "Recapitular la Cuba de los 90." La Gaceta de Cuba 3 (Mayo-Junio): 60.

Acanda, Jorge Luis. 2002. Sociedad Civil y Hegemonía. Havana: Centro de Investigación y Desarollo de la Cultura Cubana 'Juan Marinello'. Ali, Tariq. 2008. Pirates of the Caribbean: Axis of Hope. London and New York: Verso. 
Armengol, Roberto I. 2013. "Competitive Solidarity and the Political Economy of Invento." Paper presented at the Cuba in Transition: Volume 23, Annual Proceedings of the Conference of the Association for the Study of the Cuban Economy (ASCE), Miami, FL, August 1-3. https://www.ascecuba.org/pub lications/annual-proceedings/cuba-in-transition-volume-23/. Accessed July 10, 2019.

Armony, Ariel. 2003. "Civil Society in Cuba: A Conceptual Approach.” In Religion, Culture and Society: The Case of Cuba, edited by Margaret E. Crahan, 17-36. Washington, DC: Woodrow Wilson Center Reports on the Americas.

Badiou, Alain. 2007. The Century. London: Polity Press.

Bain, Mervyn J. 2008. "Corruption in Cuba: Castro and Beyond." Book review. The Historian (June 22): 319-29.

Berg Rundle, Mette Louise. 2001. "Tourism, Social Change and Jineterismo in Contemporary Cuba." The Society for Caribbean Studies Annual Conference Papers, Vol. 2. http://community-languages.org.uk/SCS-Papers/olv2p3.pdf. Accessed July 10, 2019.

Berry, Maya J. 2010. "From 'Ritual' to 'Repertory': Dancing to the Time of the Nation." Afro-Hispanic Review 29 (1): 55-76.

Bray, Donald W., and Marjorie Woodford Bray. 2002. "Introduction: The Cuban Revolution and World Change." Latin American Perspectives 29 (3): 3-17.

Brotherton, Sean Pierre. 2005. "Macroeconomic Changes and the Biopolitics of Health in Cuba's Special Period." Journal of Latin American Anthropology 10 (2): 339-69.

Brundenius, Claes. 2002. "Whither the Cuban Economy After Recovery? The Reform Process, Upgrading Strategies and the Question of Transition.” Journal of Latin American Studies 34: 365-95.

Bye, Vegard. 2013. "Possible Political Transformations in Cuba in the Light of Some Theoretical and Empirically Comparative Elements." Cuba in Transition: Volume 23, Annual Proceedings of the Conference of the Association for the Study of the Cuban Economy (ASCE), Miami, FL, August 13. https://www.ascecuba.org/publications/annual-proceedings/cuba-in-transi tion-volume-23/. Accessed July 10, 2019.

Carranza Valdés, Julio. 1991. "The Current Situation in Cuba and the Process of Change.” Latin American Perspectives 18 (2): 10-17.

Corrales, Javier. 2001. "Strong Societies, Weak Parties: Regime Change in Cuba and Venezuela in the 1950s and Today." Latin American Politics and Society 43 (2): 81-113. 
de la Fuente, Alejandro. 1998. "Race, National Discourse, and Politics in Cuba: An Overview." Latin American Perspectives 25 (3): 43-69.

Domínguez, María Isabel. 1998. "Generaciones y mentalidades." Temas 14 (Abril-Junio): 26-34.

Douglas, Mary. 2001. Implicit Meanings: Essays in Anthropology. London and Boston: Routledge and Kegan Paul.

Eckstein, Susan. 2009. "Remittances and Their Unintended Consequences in Cuba." World Development 38 (7): 1047-1055.

Eckstein, Susan, and Lorena Barberia. 2002. "Grounding Immigrant Generations in History: Cuban Americans and Their Transnational Ties.” International Migration Review 36 (3): 799-837.

Escobar, Arturo. 2001. Encountering Development: The Making and Unmaking of the Third World. Princeton, NJ: Princeton University Press.

Escobar, Arturo. 2004. "Beyond the Third World: Imperial Globality, Global Coloniality and Anti-Globalisation Social Movements." Third World Quarterly 25 (1): 207-30.

Fernandes, Sujada. 2006. Cuba Represent! Cuban Arts, State Power and the making of New Revolutionary Cultures. Durham and London: Duke University Press.

Fernández Estrada, Julio Antonio. 2017. "Sed de izquierda." On Cuba Magazine, April 26. http://oncubamagazine.com/columnas/sed-de-izquie rda/. Accessed July 10, 2019.

Gluckman, Max. 1940. "Analysis of a Social Situation in Modern Zululand." Bantu Studies 14 (1): 1-30. https://doi.org/10.1080/02561751.1940.967 6107.

Gluckman, Max. 1979. "Introduction." In The Craft of Social Anthropology, edited by Arnold Leonard Epstein, xv-xxiv. New York and Oxford: Pergamon Press.

Gold, Marina. 2011. "Urban Gardens: Private Property or the Ultimate Socialist Experience?" In Cuban Intersections of Literary and Urban Spaces, edited by Carlos Riobó, 25-48. New York: State University New York Press.

Gold, Marina. 2015. People and State in Socialist Cuba: Ideas and Practices of Revolution. New York: Palgrave Macmillan.

Gold, Marina. 2016. "Capitalist Ventures or Solidarity Networks? SelfEmployment in Post-Soviet Cuba." In Anthropologies of Value: Cultures of Accumulation Across the Global North and South, edited by Luis Fernando Angosto-Ferrández and Geir Henning Presterudsteun, 132-54. London: Pluto Press. 
Gold, Marina. 2020. "Matrifocality Against Corporate Power: The Egalitarian Potential of Cuban Cuentapropistas." In After the Pink Tide: Corporate State Formations and New Egalitarianisms in Latin America, edited by Marina Gold and A. Zagato. Berghahn Books.

González Cruz, E. 2010. "Necesidad de cambiar nuestra realidad desde el socialismo." Granma, February 26.

Gordy, Katherine. 2015. Living Ideology in Cuba: Socialism in Principle and Practice. Ann Arbor: University of Michigan Press.

Guanche, Julio Cesar. 2008. El continente de lo posible: Un examen sobre la condición revolucionaria. Havana: Ruth Casa Editorial.

Härkönen, Heidi. 2016. Kinship, Love and Life Cycle in Contemporary Havana, Cuba. New York: Palgrave Macmillan.

Hernández, Rafael. 2010. "Revolution/Reform and Other Cuban Dilemmas." Socialism and Democracy 24 (1): 9-29.

Hernandez-Reguant, Ariana. 2009. "Writing the Special Period." In Cuba in the Special Period: Culture and Ideology in the 1990s, edited by Ariana Hernandez-Reguant, 1-20. New York: Palgrave Macmillan.

Holbraad, Martin. 2014. "Revolución o Muerte: Self-Sacrifice and the Ontology of Cuban Revolution.” Ethnos 79 (3): 365-87. https://doi.org/10.1080/001 41844.2013.794149.

Holbraad, Martin. 2017. “Hasta siempre, comandante!” Blog post, January. http://aotcpress.com/articles/hasta-siempre-comandante/. Accessed July 10, 2019.

Kapcia, Antoni. 2009. "Lessons of the Special Period: Learning to March Again." Latin American Perspectives 36: 30-43.

Kapferer, Bruce. 2006. "Situations, Crisis, and the Anthropology of the Concrete." In The Manchester School: Practice and Ethnographic Praxis in Anthropology, edited by T.M.S. Evens and Don Handelman, 118-58. New York and Oxford: Berghahn Books.

Kapferer, Bruce. 2010. "Introduction: In the Event-Toward an Anthropology of Generic Moments." Social Analysis 54 (3): 1-27.

Kaufman Purcell, Susan. 1991. "Collapsing Cuba." Foreign Affairs 71 (1): 13045.

Mannheim, Karl. 1954. Ideology and Utopia. An Introduction to the Sociology of Knowledge. New York: Harcourt, Brace \& Co., Inc.

Marx, Karl. [1932] 1998. The German Ideology. New York: Prometheus Books. McMichael, Philip. 2012. Development and Social Change: A Global Perspective. Los Angeles, London, New Delhi, Singapore and Washington, DC: Sage. 
Moore, Sally Falk. 2006. "From Tribes and Traditions to Composites and Conjunctures." In The Manchester School: Practice and Ethnographic Praxis in Anthropology, edited by T.M.S. Evens \& Don Handelman, 292-310. New York and Oxford: Berghahn Books.

Otero, Gerardo, and Janice O’Bryan. 2002. "Cuba in Transition? The Civil Sphere's Challenge to the Castro Regime." Latin American Politics and Society 44 (4): 29-57.

Pedraza, Silvia. 2004. "Los Marielitos of 1980: Race, Class, Gender and Sexuality." Cuba in Transition 14: 89-102.

Pertierra, Ana Cristina. 2006. "Battles, Inventions and Acquisitions: the Struggle for Consumption in Urban Cuba." Ph.D. diss., University College London.

Pickel, Andreas. 2008. "After Fidel: Mechanisms of Regime Change." In Changing Cuba/Changing World, edited by Mauricio A. Font, 201-24. New York: Bildner Centre for Western Hemisphere Studies.

Premat, Adriana. 2003. "Small-Scale Urban Agriculture in Havana and the Reproduction of the 'New Man' in Contemporary Cuba.” Revista Europea de Estudios Latinoamericanos y del Caribe 75 (Octubre): 85-100.

Pumar, Enrique S. 2009. "The Arduous Paths of Political Transitions: A Comparison of Cuba, China and Vietnam." Cuba in Transition 19: 56-67. Rodríguez Rivera, Guillermo. 2016. "El por qué de Fidel comunista." Seguna Cita. Blog de Silvio Rodríguez. December 4. http://segundacita.blogspot.ch/ 2016/12/el-por-que-de-fidel-comunista.html. Accessed July 10, 2019.

Romeu, Jorge Luis. 2005. "Caribbean Influence on Cuban Transition." Cuba in Transition 15: 189-94.

Routon, Kenneth. 2010. Hidden Powers of the State in the Cuban Imagination. Gainesville: University Press of Florida.

Russo, Concetta. 2013. "Living Like Nikanor: The Paradox of Transition in Contemporary Cuba." Mediterranean Journal of Social Sciences 4 (9): 72734. https://doi.org/10.5901/mjss.2013.v4n9p727.

Sweig, Julia E., and Michael Bustamante. 2013. "Cuba After Communism: The Economic Reforms That are Transforming the Island." Foreign Affairs 92 (4): 101-14.

Willis, Katie. 2005. Theories and Practice of Development. New York: Routledge. Wonders, Nancy A., and Raymond Mickalowski. 2001. "Bodies, Borders, and Sex Tourism in a Globalized World: A Tale of Two Cities-Amsterdam and Havana." Social Problems 48 (4): 545-71. 
Open Access This chapter is licensed under the terms of the Creative Commons Attribution 4.0 International License (http://creativecommons.org/ licenses/by/4.0/), which permits use, sharing, adaptation, distribution and reproduction in any medium or format, as long as you give appropriate credit to the original author(s) and the source, provide a link to the Creative Commons license and indicate if changes were made.

The images or other third party material in this chapter are included in the chapter's Creative Commons license, unless indicated otherwise in a credit line to the material. If material is not included in the chapter's Creative Commons license and your intended use is not permitted by statutory regulation or exceeds the permitted use, you will need to obtain permission directly from the copyright holder.

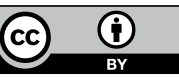

